\title{
TREE AS PASSIVE COOLING, AN ALTERNATIVE APPROACH TO ENHANCE THE THERMAL COMFORT IN BUILDING IN SOUTHEAST SULAWESI, A TROPICAL REGION
}

\author{
Aditya Rachman \\ Staf Pengajar Program Studi Teknik Mesin Fakultas Teknik Universitas Halu Oleo \\ Kampus Hijau Bumi Tridarma Andounohu Kendari 93232 \\ E-mail: aditya_rchmn@yahoo.com
}

\begin{abstract}
Reducing the role of the conventional cooling machines into the building to make the thermal comfort is so imperative as their massive energy consumption and their contribution to the global climate change. Shifting into less energy consumed cooling methods using the locally available vegetative sources as passive cooling, can be one of the appropriate methods. The aim of this study is to investigate the influence of trees to the thermal comfort performance in a building in Southeast Sulawesi, a region, geographically, located in the equator line with its high daily solar radiation intensity. It conducts an experiment on a small scale building with various tree configurations. The result shows that the trees provide the effect of lowering temperature and maintaining the relative humidity of air, contributing into making the thermal comfort-ability in the building. A comprehensive discussion, using the Psychometric chart, regarding to the reason for the phenomenon is also presented in this paper.
\end{abstract}

Keywords : trees, thermal comfort, building, Southeast Sulawesi, passive cooling

\begin{abstract}
Abstrak
Pohon sebagai penghawaan pasif, metode alternatif untuk meningkatkan kinerja kenyamanan termal bangunan di Sulawesi Tenggara, sebuah daerah tropis. Mengurangi kontribusi sistem pendinginan konvensional untuk memberikan pengaruh kenyamanan termal dalam bangunan adalah sangat penting karena besarnya konsumsi listrik dan kontribusi sistem ini terhadap perubahan iklim. Usaha untuk mengalihkan ke metode pendinginan dengan konsumsi listrik lebih sedikit dengan menggunakan sumber vegetasi lokal sebagai penghawaan pasif dapat menjadi salah satu cara yang tepat. Tujuan dari penelitian ini adalah untuk mengetahui pengaruh pohon terhadap kenyamanan termal bangunan di Sulawesi Tenggara, sebuah daerah yang secara geografis terletak di sekitar garis katulistiwa, yang memiliki intensitas radiasi matahari harian yang tinggi. Dalam penelitian ini, dilakukan eksperimen pada sebuah model rumah yang dikelilingi oleh berbagai konfigurasi pohon. Hasil dari penenlitian ini menunjukan bahwa pohon memiliki pengaruh dalam menurunkan suhu dan menjaga kelambaban udara, untuk berkontribusi dalam membuat kenyamanan termal dalam bangunan. Diskusi yang mendalam mengenai alasan tentang fenomena yang terjadi, dengan menggunakan diagram Psycometric juga disajikan dalam artikel ini.
\end{abstract}

Kata Kunci: pohon, kenyamanan termal, bangunan, Sulawesi Tenggara, penghawaan pasif

\section{Introduction}

Feeling comfortable with the living environment, such as in building, is one of the essential requirements for human being. When the heat generated by human metabolism is allowed to dissipate, it is maintaining thermal equilibrium with the surroundings, thus feeling comfort can be achieved. The condition of mind that expresses satisfaction with the thermal environment is called thermal comfort (ASHRAE, 2013). 
The environmental and personal aspects can be the indicators for the thermal comfort. The environmental factors can include air temperature, radiant temperature, air velocity and humidity. The personal aspects may come from clothing insulation and metabolic heat (HSE, 2010)

There are several methods to manage the thermal comfort in the buildings. The administrative control is one of them. It includes planning and rescheduling work times and practices, and rest schedules. The engineering controls are another one. It includes heating, making air movement and employing air conditioning (HSE, 2010)
Another approach to manage the thermal comfort is the passive cooling. It is a building design approach that focuses on heat gain control and heat dissipation in a building in order to improve the indoor thermal comfort with low or zero energy consumption (Santamouris, 1996 \& Samuel, 2013). There are many passive cooling strategies, such as natural ventilation, evaporative cooling, high thermal mass and high thermal mass with night ventilation. These passive cooling strategies rely on daily changes in temperature and relative humidity (Brown et al, 2004).

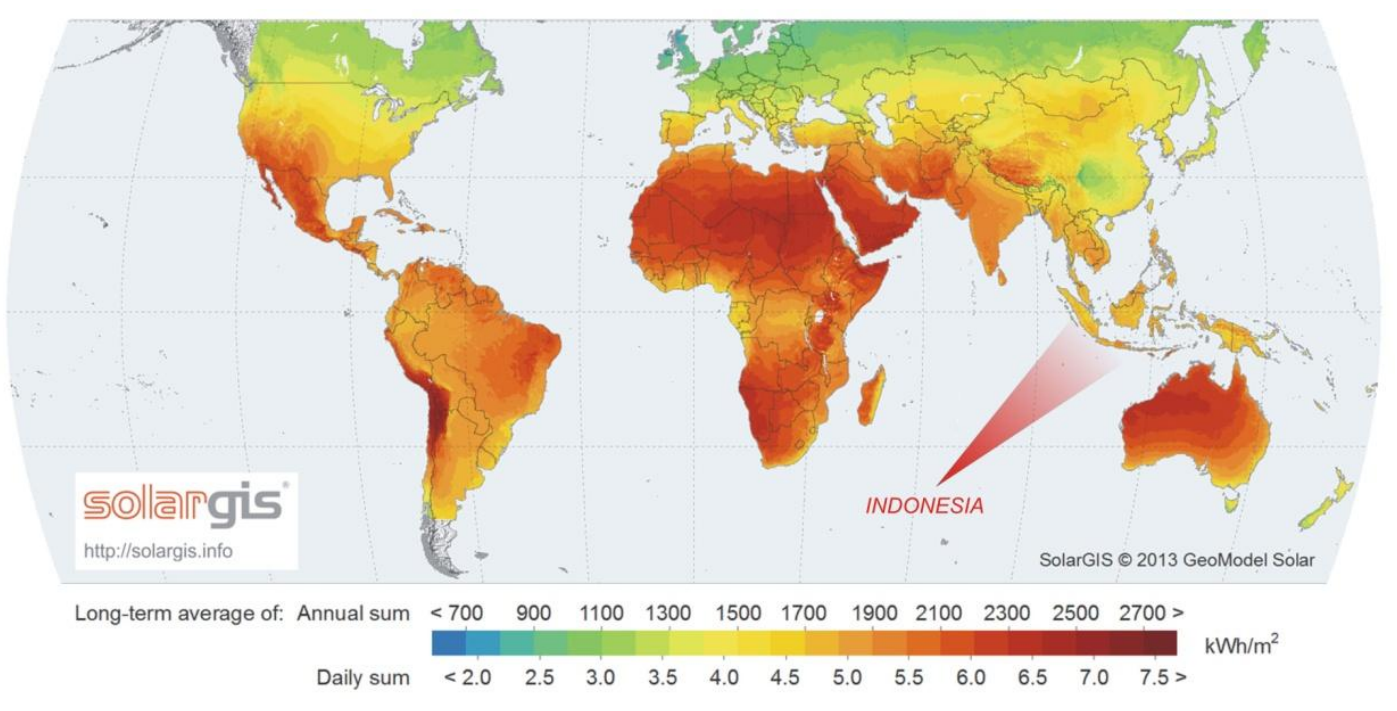

Figure 1. Global solar horizontal irradiation (Source : Solar Gis, 2013)

The passive cooling methods using the vegetation can be one of another simple and effective way to manage the thermal comfort, offering less power consumption and negative greenhouse emission. This method potentially decreases the surface and air temperatures, by providing shade and generating the evapo-transpiration (Bernatzky, 1982).

In present days, the passive cooling in building becomes a concern, as the importance on the reduction of the energy consumption to make the cost efficiency and to contribute in mitigating the global climate change. In 2010 the buildings worldwide account for a third of the total global energy use, almost a fifth of the energy related GHG emissions, approximately one-third of black carbon emissions, and an eighth to a third of F-gases (IPCC, 2014).

For Southeast Sulawesi, one of the developing provinces in Indonesia, making the thermal comfort is so less effortlessly. The location lying in the equator line causes the region receiving a fast amount of the daily solar radiation. Data in NASA (2012) shows that the daily average solar radiation in Southeast Sulawesi accounts around $5 \mathrm{KWh} / \mathrm{m}^{2}$ (the detail figures on the global solar radiation illustrated in figure 1). As the consequence, to obtain the high thermal comfort performance in the 
environment, it requires high effort to dissipate the heat from this radiation. As the conventional air cooler delivers some undesirable consequences in term of the cost and environment, the option of delivering more green method using the locally available vegetative source as passive cooling can be an alternative approach to bring the region more environmentally comfortable. This also is supported by the climatic condition, the land availability and the fertilizer soil condition of this region for this vegetative development.

The figure regarding to the influence of the trees to the local thermal comfort in this province should be very important for the designer in order to make a decision regarding to create an environmentally and less power consumed building. Even many references have included this concern; the climatic condition (average temperature and humidity characteristic) of Southeast Sulawesi should be another important consideration, highly possibly making different perspective on designing the passive cooling method based on the vegetative source in building. The aim of this study is to investigate the influence of trees on the thermal comfort in a building in Southeast Sulawesi.

\section{Literature Studies}

\section{The effect of tress in thermal comfort}

Several studies have included the discussion on the aspect of the vegetative to the thermal comfort performance. A study in Bernatzky (1982) shows a small green area potentially lowers the temperature to $3.5^{\circ} \mathrm{C}$, intensifies the relative humidity by 5 $10 \%$ to ventilate the overheated, dirty, and polluted town center, and provides fresh air. It is recommended that grassed areas and trees should be planted more systematically in towns.

Raesisi et al (1999) investigates the effect of tress as passive cooling in a city in Iran. It employs a written computer program to calculate hourly cooling load requirements by the numerical solution of the energy balance equation for the building, then being validated by comparison with field data taken from an actual house. The results indicate that for the house the cooling loads may be reduced by $10-40 \%$ by appropriate tree plantation.

Liu et al (2008) investigates the influence of trees planted as a shelterbelt in the heating consumption in a building. It uses computer simulations to model the varying energy consumption of a building with or without the shelterbelt trees. The results show that the reduction of up to $18 \%$ in heating energy consumption can be achieved by planting an optimum shelterbelt of trees in appropriate situations.

Tsiros (2009) measures the air temperature under the vegetation canopy of trees in some streets under mostly light wind conditions the city of Athens Greece during a short exceptionally hot weather period in 2007. It is found that the average cooling effect at a noon may reaches to $1.6{ }^{\circ} \mathrm{C}$ and at an afternoon, it may reaches to $2.2^{\circ} \mathrm{C}$. The highest cooling effect of $2.2{ }^{\circ} \mathrm{C}$ is found to be reached in a street with high tree shaded area and minimal traffic load.

Lin et al (2010) investigates the effect of shade trees on the air and surface-soil temperature reduction under canopy in subtropical Taipei City Taiwan. It uses an experiment on ten species of trees and two species of bamboo, which had tightly clustered tall stems and spreading branches resembling trees in shape. In the comparison with the nearby un-shaded open space, air temperatures under the canopies are 0.64 to $2.52{ }^{\circ} \mathrm{C}$ lower, whereas the surface-soil temperatures are 3.28 to $8.07{ }^{\circ} \mathrm{C}$ lower.

\section{Thermal comfort}

Instead of enable figuring the condition of mind that expresses satisfaction with the thermal environment, the assessment of the thermal comfort is conducted by subjective evaluation (ASHRAE Std.55, 2004). Maintaining this standard of thermal comfort for occupants of buildings or other enclosures is one of the important objectives of the Heating, Ventilation, and Air Conditioning (HAVC) design engineers (ASHRAE, 2013). In the ASHRAE Std. of 552013 , for thermal comfort purposes for the human occupancy, temperature could range between approximately 19.5 and $27.7{ }^{\circ} \mathrm{C}$ and that of the relative humidity to be controlled less than $65 \%$.

\section{Southeast Sulawesi and its climatic condition}

Southeast Sulawesi lies on the southeast peninsula of Sulawesi. Geographically, it is located in the southern part of the equator, between $02^{\circ} 45^{\prime}$ and $06^{\circ} 15^{\prime}$ south latitude, and between $120^{\circ} 45^{\prime}$ and $124^{\circ} 45^{\prime}$ east longitude. The larger part of this region is water (sea) $\left(74 \%\right.$ or $\left.110.000 \mathrm{~km}^{2}\right)$. The 
land $(26 \%)$ consists of the main island and several smaller islands with the total area of approximately $38.140 \mathrm{~km}^{2}$ (BPS Southeast Sulawesi, 2012).

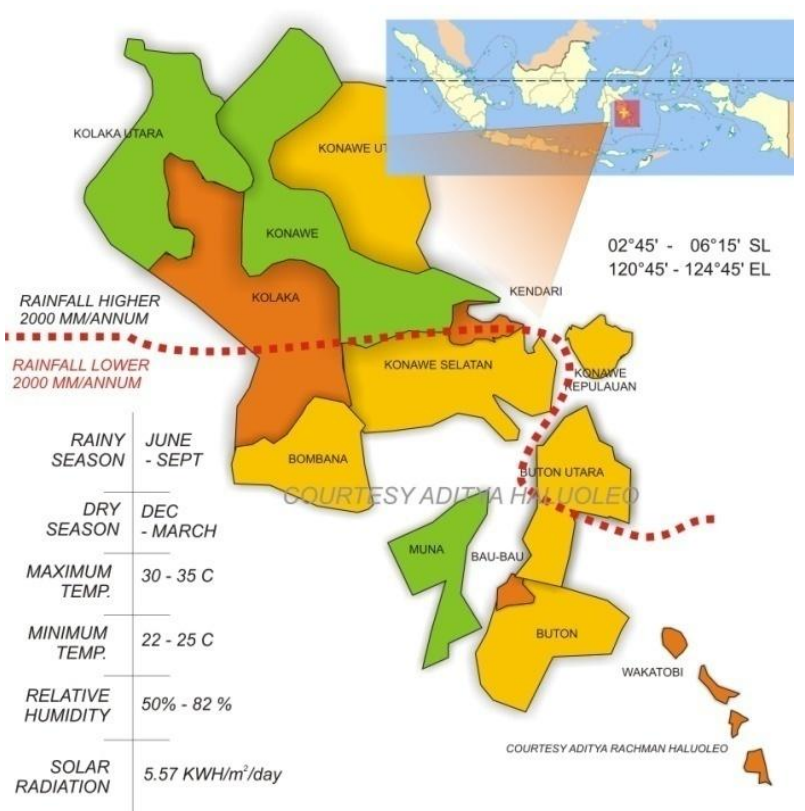

Figure 2. Southeast Sulawesi : Map and climate

Southeast Sulawesi has two seasons: dry and rainy seasons. The dry season occurs from June to September and the rainy season occurs from December to March. As the location around the equator line, Southeast Sulawesi has the tropical climate. The range of the average maximum temperature is $30^{\circ} \mathrm{C}$ to $35^{\circ} \mathrm{C}$, and the average minimum temperature is $22^{\circ} \mathrm{C}$ to $25^{\circ} \mathrm{C}$ with the relative humidity around $50 \%-82 \%$ (BPS Southeast Sulawesi , 2012).

\section{Methodology}

The methodology of generating this study is an experiment on a model of a building surrounding by tress. This study proposes a small scale building model in the size of $3 \times 3 \times 4 \mathrm{~m}^{3}$ (see Figure 3-6). Trees with various configurations are located around the building. In the configuration 1, the building is surrounded by 4 trees, each of which is located in the corner. In the configuration 2 , the location of trees is only at the rear corner, while in the configuration 3 , the tress are located in the front corner. In the configuration 4 , no tress is applied around building.

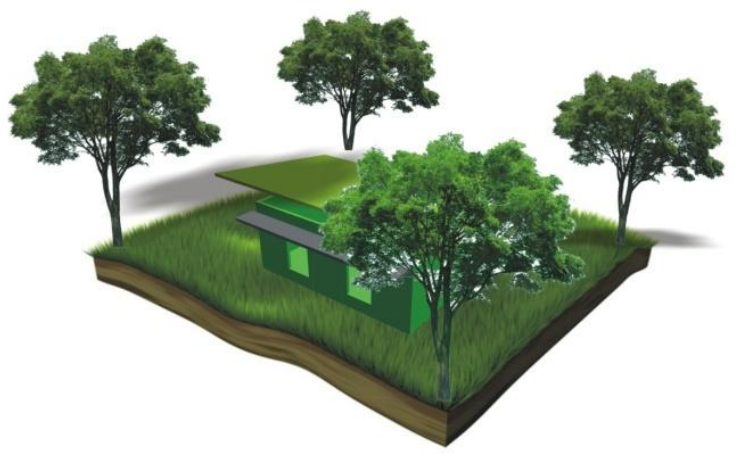

Figure 3. The model in configuration 1

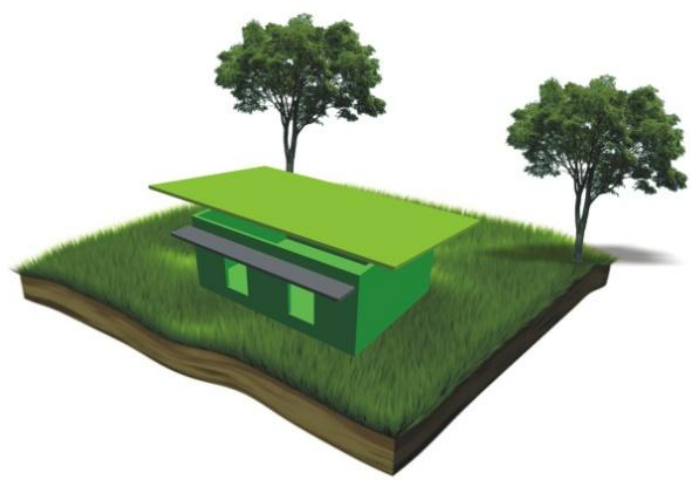

Figure 4. The model in configuration 2

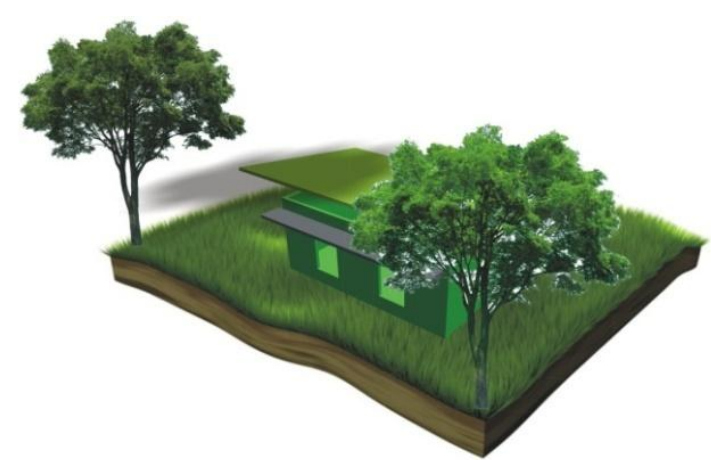

Figure 5. The model in configuration 3

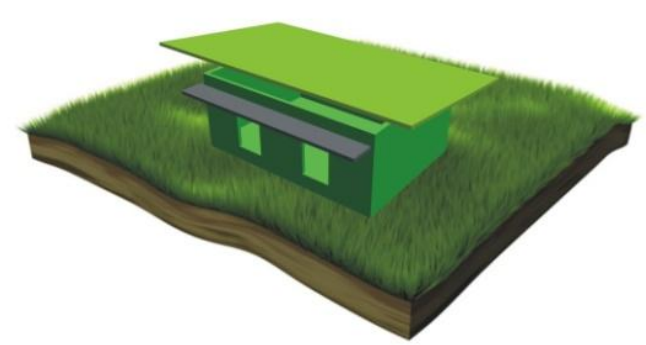

Figure 6. The model in configuration 4 


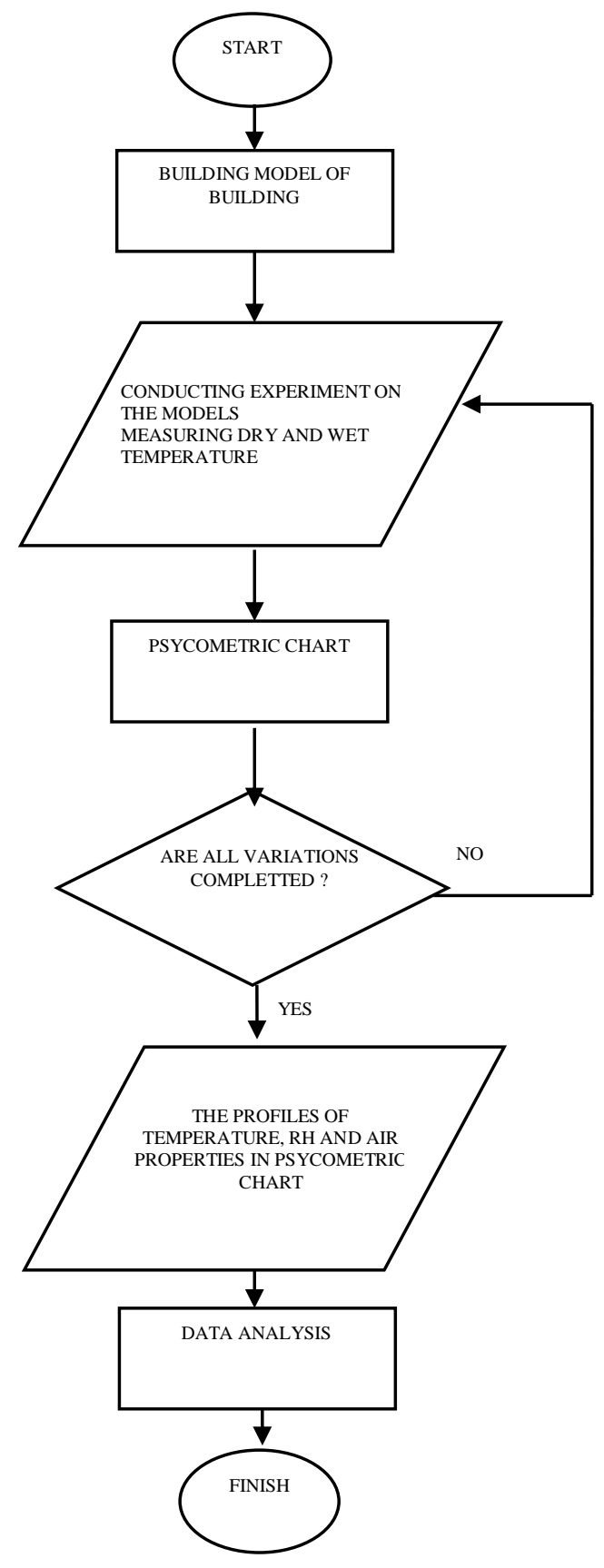

Figure 7. The flowchart diagram

In the building, thermometers to measure the dry and wet temperatures are placed. The data of the dry and wet temperatures are utilized to predict the amount of the humidity in the building, using the Psychometric chart. The data is obtained from September to October 2013, at which the average temperatures are high. The detail of the experiment stages is shown in figure 7 .

\section{Result and Discussion}

Figure 8 shows the average dry and wet bulb temperatures in the building and the average outside temperatures for all proposed configurations. The pattern on the temperatures for all configurations is similar. In the morning, they are low, then as the sun above the head (at noon), the temperature increases. It continues increasing at 13.00 , before decreasing at the afternoon.

As seen in Figure 8, at 08.00 (morning), for the configuration 1 , the inlet dry temperature is around $27^{\circ} \mathrm{C}$, while that at the outside, it is around $30^{\circ} \mathrm{C}$. At 12.00 (noon), the inlet dry temperature is around $30^{\circ} \mathrm{C}$, while that at the outside, it is around $32.5^{\circ} \mathrm{C}$. At the afternoon, it decreases to $26.5^{\circ} \mathrm{C}$. The average maximum dry temperature in the building is around $30,5^{\circ} \mathrm{C}$ at 13.00 (noon).

For the configuration 2, at 08.00 (morning), the average inlet dry temperature is around $28^{\circ} \mathrm{C}$, then increasing to almost $31^{\circ} \mathrm{C}$ at 12.00 (noon). The average maximum dry temperature inside the building is around $31{ }^{\circ} \mathrm{C}$, at 13.00 (noon). For the configuration 3 , the pattern and the amount of the temperatures are generally similar to that of the configuration 3 .

For the configuration 4 , at 08.00 , the average dry temperature in the building is around $28,5^{\circ} \mathrm{C}$. At 13.00 (noon), it is around $32^{\circ} \mathrm{C}$, then decreasing to $29^{\circ} \mathrm{C}$ at 15.00 .

Based on previous results, there is tendency that the buildings with tress offer the low temperature environment daily. In this study, the maximum temperature difference is around $2,5^{\circ} \mathrm{C}$, in the case of that of the configuration 1 and the configuration 4 at 15.00 (afternoon).

Figure 9 shows the relative humidity (RH) from the proposed configurations, obtained from applying the dry and wet temperature data into the Psychometric chart. For the configuration 1, in the morning, the $\mathrm{RH}$ is around $76 \%$, then decreasing to $73 \%$ at 10.00 . At the 13.00 , the amount of this humidity decreases to $71 \%$, before increasing again to around $74 \%$ in afternoon.

For the configuration 2 and 3 the pattern is quite similar. In 08.00 (morning), the amount of the humidity is around $74 \%$, then decreasing to $68 \%$ at 10.00. At 12.00 , the relative humidity is around $66 \%$ (the lowest at the day), before recovering to around $72 \%$ at 15.00 . 


\section{DINAMIKA Jurnal Ilmiah Teknik Mesin}

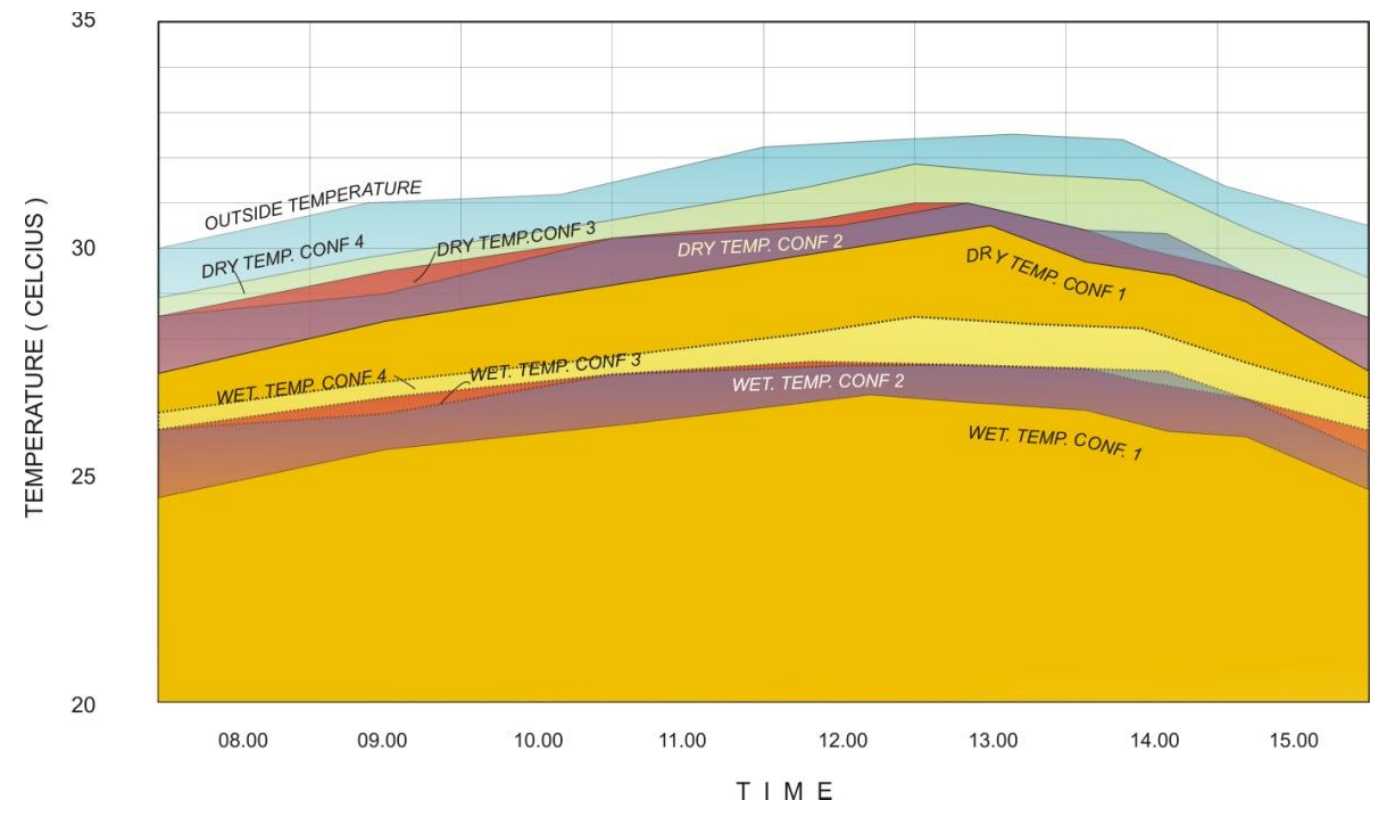

Figure 8 . The dry and wet temperatures in all proposed configurations

For the configuration 4 , the pattern is similar, but the amount is lower than those of the previous configurations. At 08.00, the amount of the humidity is around $72 \%$, then, it decreases sharply to almost $62 \%$ at 12.00 (noon), before recovering to $70 \%$ at 15.00 .
Based on these results, the existence of the tress enables the building to maintain the relative humidity at high amount as the decreasing on the amount of the humidity is not as extreme as the building with no tress (configuration 4).

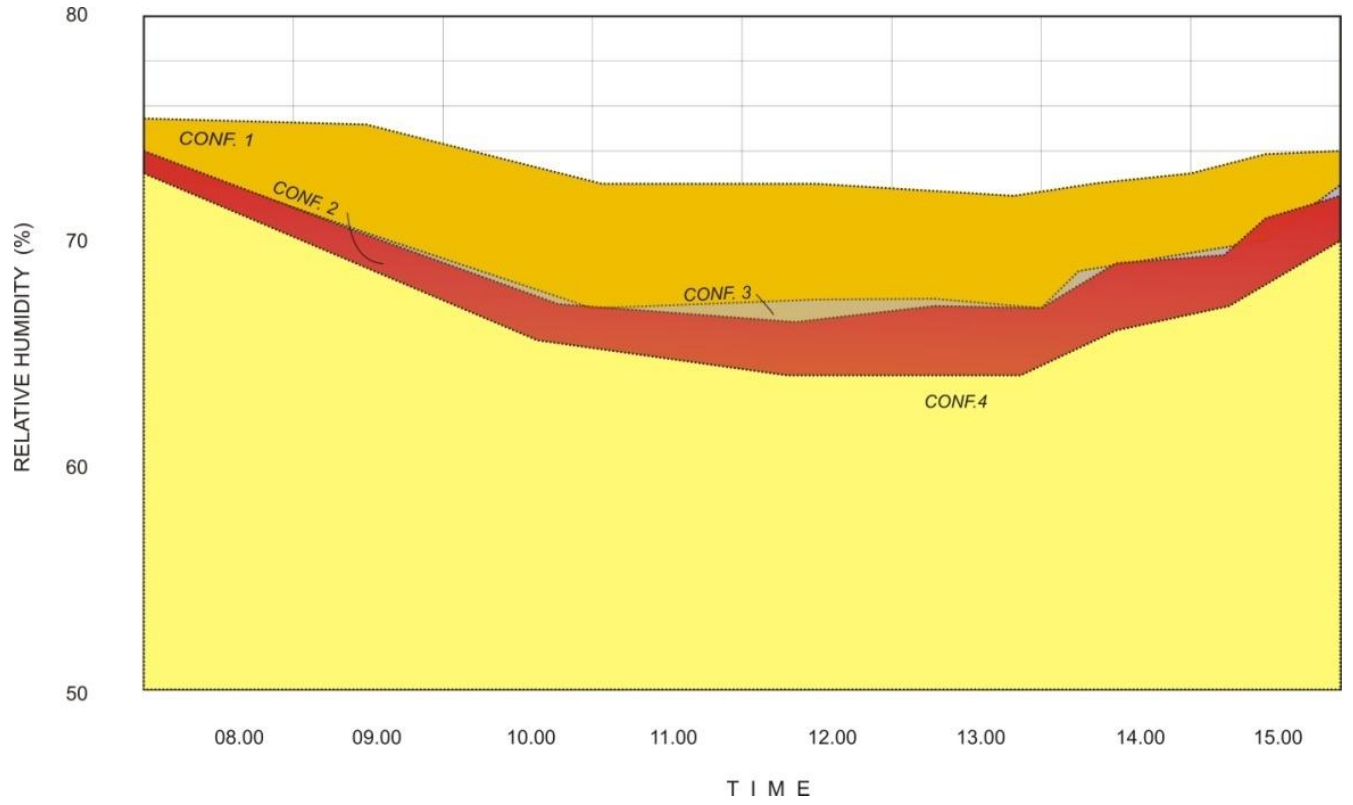

Figure 9. The relative humidity in all proposed configurations 


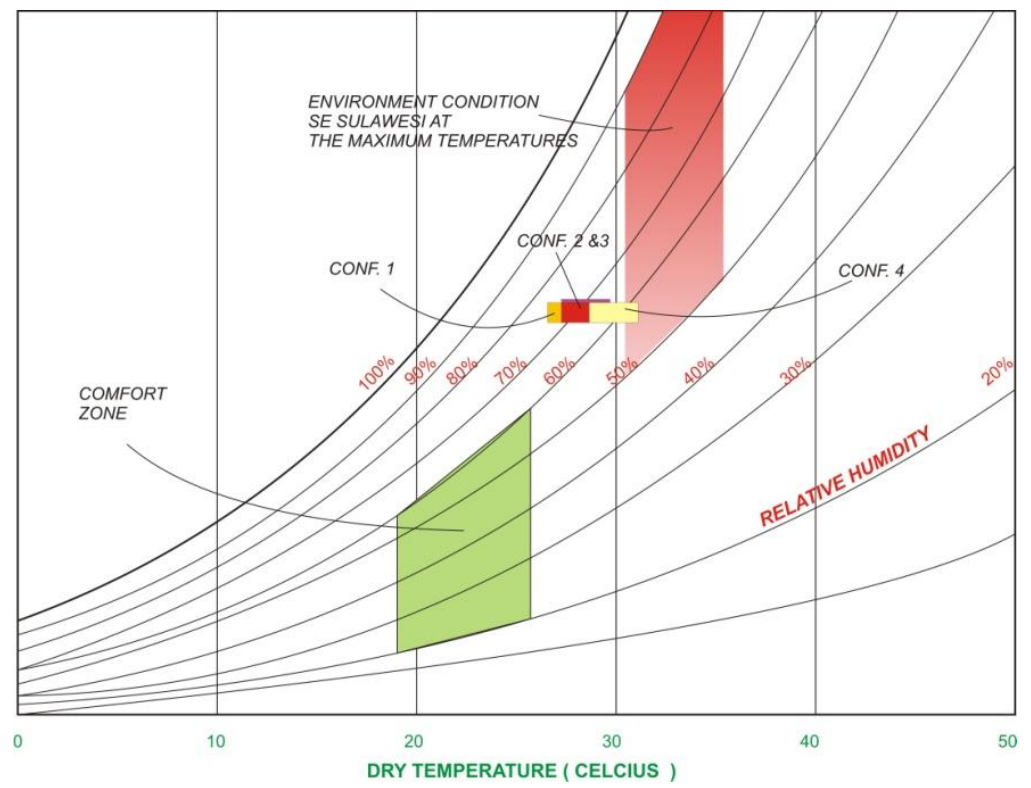

Figure 10. The air properties in all proposed configurations and their comparisons to those of the comfort zone and the environmental condition (at the maximum temperature condition) in Southeast Sulawesi

The effect of tress to make the shading effect, lowering temperature, and the evaporatetranspiration effect can be the reasons for these phenomena. The following section explains the reasons for this phenomenon. As the sun goes up, the temperatures increase. When no air cooling devices, it causes the building temperature increasing and the relative humidity decreasing. The existence of tree can make the shading effect, to decrease the amount of the sun radiation goes into building, lowering the temperature. Indeed, the evaporative-transpiration effect of the vegetative cooling device makes more water evaporated into the air. The water not only contributes into the cooling process, but also adds vapor into the air, maintaining the relative humidity.

Figure 10 shows the air properties inside building on the proposed configurations and their comparison to those of the comfort zone (ASHRAE Standard) in the Psychometric chart. This figure indicates that there is a distance between the region of the comfort zone and the surrounding environment at its maximum temperatures as well as the building with no tress. As the trees are incorporated, the distance on the zones decreases. This can be seen from the figure that the more tress (as configuration 1,2 and 3) are, the closer is the air property zone to the comfort zone.

\section{Conclusion}

This study has investigated the effect of trees on the thermal comfort in a building in Southeast Sulawesi. Following section presents some conclusion that can be drawn.

The effect of tress in the building is to lower the average temperature and to maintain the relative humidity. The maximum decreasing temperature obtained by the incorporation of tree is around $2,5^{\circ} \mathrm{C}$ (at afternoon). In comparison to that of no tress available, the decrease of the relative humidity at noon is considerably lower for those with trees available. In the Psychometric chart, it is indicated that the existence of tress lowers the distance of the air property zone to the comfort zone.

\section{References}

ANSI/ASHRAE Standard 55. 2013. "Thermal Environmental Conditions for Human Occupancy"

ASHRAE-55. 2004, ASHRAE Standard- 55, American Society of Heating Refrigeration and Air-Conditioning Engineers Inc., Atlanta.

Bernatzky A. 1982, "The contribution of tress and green spaces to a town climate “, Energy 
and Buildings, Volume 5, Issue 1, September 1982, Pages 1-10

BPS Southeast Sulawesi. 2012, “Geography”

Brown Z, DeKay M. 2000, "Sun, Wind \& Light: Architectural Design Strategies", 2nd Edition Paperback - October 24, Publisher: Wiley; 2 edition

Health Savety Executive (HSE ). 2010, “The six basic factors",

http://www.hse.gov.uk/temperature/thermal/ factors.htm

IPCC. 2014, “ Assessment Report "Climate Change 2014: Mitigation of Climate Change". IPCC Third Assessment Report Working Group III: Mitigation

Lin BS, Lin YJ. 2010, "Cooling Effect of Shade Trees with Different Characteristics in a Subtropical Urban Park", HortScience, January vol. 45no. $183-86$

Liu Y, Harris DJ. 2008, “Effects of shelterbelt trees on reducing heating-energy consumption of office buildings in Scotland", Applied Energy, Volume 85, Issues 2-3, February-March, Pages 115-127

NASA. 2012, "Surface Meteorology and Solar Energy : A Renewable Energy Resource Web Site”, NASA Langley Research Center Atmospheric Science Data Center Surface meteorological and Solar Energy (SSE) web portal supported by the NASA LaRC POWER Project

Raeissi S, Taheri M. 1999, "Energy saving by proper tree plantation". Building and Environment, Volume 34, Issue 5, 1 September, Pages 565-570,

Samuel L, Shiva DG, Nagendra SM, Maiya MP. 2013, "Passive alternatives to mechanical air conditioning of building: $A$ review". Building and Environment66: 5464. doi:10.1016/j.buildenv.2013.04.016.

Santamouris M, Asimakoupolos D. 1996, "Passive cooling of buildings"(1st ed.). 35-37 William Road, London NW1 3ER, UK: James \& James (Science Publishers) Ltd. ISBN 1-873936-47-8.

Solar Gis, 2013, "Solar potential - global horizontal irradiation”. http://solargis.info/doc/free-solar-radiationmaps-GHI

Tsiros IX. 2010, “Assessment and energy implications of street air temperature cooling by shade tress in Athens (Greece) under extremely hot weather conditions", Renewable Energy, Volume 35, Issue 8, August, Pages 1866-1869 